\title{
ESGE-ESGENA technical specification for process validation and routine testing of endoscope reprocessing in washer-disinfectors according to EN ISO 15883, parts 1, 4, and ISO/TS 15883-5
}

ESGE

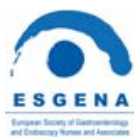

Ulrike Beilenhoff ${ }^{1}$, Holger Biering ${ }^{2}$, Reinhard Blum ${ }^{3}$, Jadranka Brljak ${ }^{4}$, Monica Cimbro ${ }^{5}$, Jean-Marc Dumonceau ${ }^{6}$, Cesare Hassan ${ }^{7}$, Michael Jung $^{8}$, Christiane Neumann ${ }^{9}$, Michael Pietsch ${ }^{10}$, Lionel Pineau ${ }^{11}$, Thierry Ponchon ${ }^{12}$, Stanislav Rejchrt ${ }^{13}$, Jean-François Rey ${ }^{14}$, Verona Schmidt ${ }^{15}$, Jayne Tillett ${ }^{16}$, Jeanin van Hooft ${ }^{17}$

Institutions

1 ESGENA Scientific Secretary, Ulm, Germany

2 Grevenbroich, Germany

3 Olympus Europa, Hamburg, Germany

4 University Hospital KBC-Zagreb-Rebro, Zagreb, Croatia

$5 \mathrm{CBC}$ (Europe), Nova Milanese, Italy

6 Gedyt Endoscopy Center, Buenos Aires, Argentina

7 Digestive Endoscopy Unit, Catholic University, Rome, Italy

8 2nd Department of Internal Medicine, Katholisches Klinikum, Mainz, Germany

9 ESGENA Past President, Birmingham, UK

10 Department of Hygiene and Infection Prevention, Medical Center, University Hospital, Mainz, Germany

11 Biotech Germande, Marseille, France

12 Digestive Diseases Department, Hôpital Edouard Herriot, Lyon, France

13 2nd Department of Internal Medicine, Charles University Teaching Hospital, Hradec Králové, Czech Republic

14 Institut Arnault Tzanck, St. Laurent du Var, France

15 Microbiology and Hygiene Department, Chemische Fabrik Dr. Weigert, Hamburg, Germany

16 St. Woolos Hospital, Newport, UK

17 Department of Gastroenterology and Hepatology, Academic Medical Center, Amsterdam, The Netherlands

Bibliography

DOI https://doi.org/10.1055/s-0043-122073

Published online: 16.11.2017 | Endoscopy 2017; 49:

1262-1275 | @ Georg Thieme Verlag KG Stuttgart · New York ISSN 0013-726X
Corresponding author

Ulrike Beilenhoff, ESGENA Scientific Secretariat, FerdinandSauerbruch-Weg 16, 89075 Ulm, Germany

info@esgena.org

\section{STATEMENTS}

1 Prerequisites. The clinical service provider should obtain confirmation from the endoscope washer-disinfector (EWD) manufacturer that all endoscopes intended to be used can be reprocessed in the EWD.

2 Installation qualification. This can be performed by different parties but national guidelines should define who has the responsibilities, taking into account legal requirements. 3 Operational qualification. This should include parametric tests to verify that the EWD is working according to its specifications.

4 Performance qualification. Testing of cleaning performance, microbiological testing of routinely used endoscopes, and the quality of the final rinse water should be considered in all local guidelines. The extent of these tests depends on local requirements. According to the results of type testing performed during EWD development, other parameters can be tested if local regulatory authorities accept this. Chemical residues on endoscope surfaces should be searched for, if acceptable test methods are available. 5 Routine inspections. National guidelines should consider both technical and performance criteria. Individual risk analyses performed in the validation and requalification processes are helpful for defining appropriate test frequencies for routine inspections. 
This technical specification is an official statement of the European Society of Gastrointestinal Endoscopy (ESGE) and the European Society of Gastroenterology and Endoscopy Nurses and Associates (ESGENA). It addresses validation and routine testing of automated reprocessing procedures in washer-disinfectors for thermolabile endoscopes, complying with the final version of EN ISO 15883, parts 1, 4, and ISO/TS 15883-5.In this update of the ESGE-ESGENA 2007 statement, in addition four national guidelines on validation and routine testing of endoscope washer-disinfectors were reviewed by experts in the field.

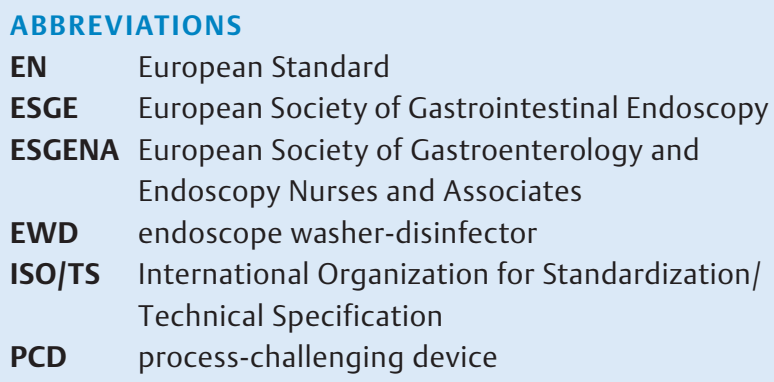

\section{Scope of this technical specification}

Quality assurance in hygiene and infection control is an important tool in preventing nosocomial infections, whether endoscopy procedures are performed in hospitals, in private clinics, or doctors' offices. Quality assurance is also a legal obligation.

Validation and routine testing procedures have been common practice in the monitoring of sterilization processes in central sterilization units for a long time. More recently, the implementation of process validation and routine testing of automated reprocessing of thermolabile endoscopes has been an important step towards improving quality assurance and patient safety.

The European Society of Gastrointestinal Endoscopy (ESGE) and European Society of Gastroenterology Nurses and Associates (ESGENA) first published a guideline on this topic in 2007 [1], based on the European and International Standard EN ISO 15883 [2-4]. In the meantime, several European countries have developed national guidelines on validation and routine testing of endoscope washer-disinfectors (EWDs) [5-8].

This ESGE-ESGENA technical specification addresses the validation and routine testing of automated reprocessing procedures in EWDs for thermolabile endoscopes and their accessories; it complies with EN ISO 15883, which describes in detail the requirements of design and function of EWDs [2,3]. The advantages of validation processes, which are based on dedicated and proven test methods for benchmarking, include:

- Reduction in the risk of endoscopy-related infections by improvement in the efficacy of reprocessing procedures;

- Increased safety of patients and staff;

- Better transparency of the reprocessing process;

- Earlier detection of weaknesses and defects of washerdisinfectors.

\section{GLOSSARY}

Clinical service provider An organization, person or group of persons legally responsible for the provision of a clinical service. This could be an institution, hospital, or department, or a doctor working on his/her own premises.

Installation qualification (IQ) Inspections of the endoscope washer-disinfector (EWD) and EWD accessories and their installation beginning immediately after arrival at the site of installation (at the reprocessing area).

Operational qualification (OQ) Inspections and tests done to confirm that the EWD functions according to its operational specifications.

Performance qualification (PQ) Final inspections and tests to confirm that the EWD is effective for endoscope reprocessing in the reprocessing area.

Process chemicals All chemicals used during the reprocessing procedures, including detergents, disinfectants, rinsing aids, water.

Surrogate device Item designed to represent construction elements of endoscope-specific characteristics affecting the flow conditions in an endoscope. Construction elements can include channel length and diameter, connectors, channel separators, port closures, return valves, etc. (EN ISO 15883, part 4).

Type testing Tests to be performed by the manufacturer in the frame of the development of new EWD devices. User Person or department using the endoscopic and reprocessing equipment within a clinical service provider. Validation Documented procedure for obtaining, recording, and interpreting the results required to establish that a process will consistently yield outcomes complying with predetermined specifications.

Working area for endoscope reprocessing Area of a health care facility where thermolabile endoscopes are reprocessed (cleaned, disinfected, and dried).

Works testing Tests to be performed on each individual EWD at the end of the manufacturing process and before the EWD leaves the factory.

Validation of protocols for manual endoscope reprocessing procedures in general and manual steps (flushing, brushing) before the EWD process, transport processes, and storage are not within the scope of this technical specification.

This technical specification is an expert opinion and provides practical information and guidance through the validation of the entire reprocessing sequence in EWDs, including routine testing. It is based on experience of applying existing national guidelines and recommendations [5-8]. 


\section{Methods}

This ESGE-ESGENA technical specification is based on a multidisciplinary consensus. Gastroenterologists, endoscopy nurses, chemists, microbiologists, and industry representatives who have been involved in developing national and international guidelines and standards were invited to participate. Most of these experts were also authors of the first ESGE/ESGENA statement on this topic that was issued in 2007 [1].

A literature search did not find any prospective studies, randomized controlled trials, analyses, or pilot studies focused on validation and routine testing of EWDs. Therefore, four available national guidelines on validation and routine testing of EWDs, complying with the final version of EN ISO 15883, parts 1, 4 and ISO/TS 15883-5, were reviewed and conclusions were made, based on the experts' opinions.

\section{Aims of this technical specification}

The aims of this technical specification are:

- To support national societies and official bodies in developing or improving national recommendations for validating and routinely testing the process of reprocessing thermolabile endoscopes;

- To support individual endoscopy departments and clinical service providers in establishing local protocols for validation and routine testing of processes in EWDs.

\section{Target groups}

This technical specification provides guidance about process validation and routine testing of endoscope reprocessing in EWDs for:

- Clinical service providers who have the responsibility to meet structural and organizational requirements and to educate staff for safe use of EWDs;

- Endoscopists, endoscopy nurses and other users of EWDs, who use thermolabile endoscopes and who are responsible for safe reprocessing of endoscopy equipment;

- Hospital hygienists, microbiological personnel, microbiologists, and authorized institutions who perform regular microbiological quality control in endoscopy units;

- Manufacturers, suppliers, and authorized third parties who sell, install, and maintain EWDs for endoscope reprocessing;

- Manufacturers of thermolabile endoscopes and of process chemicals, as they provide information relevant to reprocessing procedures;

- Institutions, companies, and qualified persons who are authorized to perform validation and routine testing of endoscope reprocessing for EWDs.

\begin{tabular}{|c|c|c|}
\hline $\begin{array}{l}\text { Quality } \\
\text { management } \\
\text { by washer- } \\
\text { disinfector } \\
\text { manufacturer }\end{array}$ & \multicolumn{2}{|c|}{$\begin{array}{l}\text { Quality management } \\
\text { by clinical service provider }\end{array}$} \\
\hline $\begin{array}{l}\text { Type testing } \\
\text { Detailed } \\
\text { analysis of each } \\
\text { process } \\
\text { parameter and } \\
\text { of the } \\
\text { complete } \\
\text { reprocessing } \\
\text { cycle }\end{array}$ & $\begin{array}{l}\text { Validation } \\
\text { Evaluation of } \\
\text { reprocessing } \\
\text { cycle under } \\
\text { routine } \\
\text { conditions } \\
\text { - Check of } \\
\text { prerequisites }\end{array}$ & $\begin{array}{l}\text { Routine } \\
\text { testing } \\
\text { Evaluation of } \\
\text { outcome } \\
\text { quality by } \\
\text { technical and } \\
\text { microbiological } \\
\text { tests }\end{array}$ \\
\hline $\begin{array}{l}\text { Works testing } \\
\text { Shows } \\
\text { conformity of } \\
\text { the washer- } \\
\text { disinfector with } \\
\text { EN ISO } 15883\end{array}$ & $\begin{array}{l}\text { - Installation } \\
\text { qualification } \\
\text { - Operational } \\
\text { qualification } \\
\text { - Performance } \\
\text { qualification }\end{array}$ & $\begin{array}{l}\text { Testing of: } \\
\text { - Washer- } \\
\text { disinfector } \\
\text { - Endoscopes } \\
\text { - Water }\end{array}$ \\
\hline
\end{tabular}

Fig. 1 Main elements of the quality assurance system for endoscope washer-disinfectors.

\section{Introduction to validation and routine testing}

The clinical service provider is responsible for implementing effective protocols for the complete reprocessing procedure, covering manual cleaning and automated steps for reprocessing endoscopes. The correct functioning of automated EWDs according to the manufacturer's specifications is an essential element of this procedure. Routine maintenance and microbiological surveillance are the current tools for regular quality control.

The standard EN ISO 15883 consists of seven parts. Three parts are relevant to endoscope reprocessing:

- Part 1 states the general requirements and definitions for all EWDs [2].

- Part 4 defines the special requirements for the design of EWDs and for reprocessing of heat-sensitive instruments such as thermolabile endoscopes. In addition, EN ISO 15883-4 includes checking for whether correct reprocessing results are obtained with all endoscope types to be reprocessed in the service provider facility under on-site conditions (e.g., depending on water quality, power supply) [3];

- Part 5 details test soils and methods for demonstrating cleaning efficacy [4].

Quality assurance systems applied to EWDs comprise four main parts: type testing, works testing, validation testing, and routine testing (see $>$ Fig. 1). 
- Table 1 Responsibilities and qualification for validation and routine testing.

\begin{tabular}{|c|c|c|c|}
\hline & Responsibility & $\begin{array}{l}\text { Options for involved persons/ } \\
\text { groups }\end{array}$ & Qualifications of personnel \\
\hline Validation: Prerequisites & Clinical service provider & \multirow{3}{*}{$\begin{array}{l}\text { - EWD manufacturer } \\
\text { - Authorized supplier } \\
\text { - Authorized third party } \\
\text { - Endoscopy department }\end{array}$} & \multirow{3}{*}{$\begin{array}{l}\text { Expertise in regulatory issues, } \\
\text { technical and electrical issues of } \\
\text { EWDs, chemicals, flexible endo- } \\
\text { scopes, and special equipment }\end{array}$} \\
\hline Validation: Installation qualification & Clinical service provider & & \\
\hline Validation: Operational qualification & Clinical service provider & & \\
\hline Validation: Performance qualification & Clinical service provider & \multirow[b]{2}{*}{$\begin{array}{l}\text { - EWD manufacturer } \\
\text { - Authorized supplier } \\
\text { - Authorized third party } \\
\text { - Endoscopy staff } \\
\text { - Microbiological and chemical } \\
\text { laboratory services } \\
\text { - Microbiological staff } \\
\text { - Hygienists } \\
\text { - Infection control nurses }\end{array}$} & \multirow{2}{*}{$\begin{array}{l}\text { Microbiological and chemical } \\
\text { expertise } \\
\text { Technical understanding of the } \\
\text { EWD and flexible endoscopes }\end{array}$} \\
\hline Routine testing & Clinical service provider & & \\
\hline
\end{tabular}

Type testing is the responsibility of the EWD manufacturer, and serves to demonstrate that the EWD complies with the relevant parts of EN ISO 15883. During type testing, prototypes of the EWD are used to analyze separately each individual step of the reprocessing cycle (e. g., with respect to cleaning efficacy, disinfection efficacy, water quality, chemicals), followed by evaluation of the complete reprocessing cycle. In addition, the type testing provides reference data for further validation and use of the EWD.

In addition to type testing, manufacturers must perform works testing. During works testing, each individually manufactured EWD is checked on the basis of internal quality parameters before it leaves the manufacturing site.

Type testing and works testing are prerequisites for obtaining CE marking (Conformité Européene; a declaration that a product complies with the relevant European legislation). The manufacturer should provide a list of endoscope models that can be reprocessed in the particular EWD.

Validation is the responsibility of the clinical service provider. It proves that the entire reprocessing procedure gives reproducible and consistent results that comply with predetermined specifications in the location where it will be applied. Single parameters can be defined as indicators. The validation procedure of EWDs includes the following steps:

- Installation qualification (IQ)

- Operational qualification (OQ)

- Performance qualification (PQ)

Routine inspections are the responsibility of the clinical service provider. These inspections cover daily functional tests and checks of technical parameters as well as periodic testing that includes microbiological tests.

Requalification is the responsibility of the clinical service provider. It includes parts of the operational and performance qualification.

\section{Responsibilities of the clinical service provider and staff qualifications}

It is the responsibility of the clinical service provider to ensure that all steps of the reprocessing procedures of medical devices are performed according to national guidelines and manufacturers' recommendations, in order to meet predefined specifications (cleanliness, disinfection, function, and application safety). The validation and routine testing of automated procedures is a key element in this process. The validation of EWDs must be performed at the site where the EWD is used clinically. Qualified companies/persons may perform the validation and routine testing on behalf of the clinical service provider. It is highly recommended that the company or persons performing such procedures have expert knowledge in all relevant areas, such as microbiology, hygiene and infection control, EWD technical and electrical issues, chemicals, thermolabile endoscopes, quality management, risk management, and regulatory issues ( $\triangleright$ Table $\mathbf{1}$ ).

It is the responsibility of the clinical service provider to ensure that all relevant data of the validation and routine testing of the EWD process are documented. For this purpose, the use of standard checklists is recommended. Examples of checklists are shown in Appendix 1.

\subsection{Installation qualification}

The installation qualification (IQ) is the responsibility of the clinical service provider and is usually performed by the manufacturer, the supplier, or authorized third parties.

\subsection{Operational qualification}

The operational qualification (OQ) is the responsibility of the clinical service provider. Specialized knowledge of EWD technical and electrical issues, chemicals, regulatory issues, and special equipment is required; therefore it is recommended that authorized and specially trained persons perform this element of validation. The manufacturer of the EWD must provide in- 
structions on how to test the various process parameters and functions of the EWD. The manufacturer may also need to supply appropriate specialized test equipment.

\subsection{Performance qualification}

The performance qualification (PQ) is the responsibility of the clinical service provider. Only persons/organizations with appropriate chemical/analytical and microbiological expertise should carry out these tests. Additionally, persons/organizations should have a thorough understanding of the structure and function of the tested EWD and endoscopes.

\subsection{Routine inspections}

Routine inspections are the responsibility of the clinical service provider. Routine tests can be performed by either the staff of the hygiene department of the hospital or by any external qualified laboratory on behalf of the clinical service provider. These tests can cover technical and microbiological parameters.

Microbiological tests should be performed by appropriately trained persons. The collection, culture, and interpretation of test results should be performed in close cooperation with endoscopy staff, hospital hygienists, appropriate microbiology personnel, and microbiologists, in line with national requirements. An example of required staff qualifications has been published [9].

\section{Validation procedures}

\subsection{Prerequisites}

The clinical service provider should ensure that some requirements are fulfilled before the validation procedures are started. These requirements cover environmental and structural prerequisites, such as:

- Purpose-designed reprocessing room, separate from endoscopy procedure rooms [5-8, 10,11];

- Separation of contaminated and clean working areas [5$11]$;

- Information about water quality (e. g., hardness and microbiological status) and power supply [2,3];

- Storage for process chemicals, and safe supply, according to national regulations.

These requirements also cover organizational prerequisites, such as:

- Reprocessing instructions for each medical device according to EN ISO 17664 [12];

- List of endoscopes intended for reprocessing, categorized by endoscope families [13], and considering all their respective connectors/adapters;

- Definition of test load for performance qualification [2,3].

To allow for fulfillment of some of these requirements, the EWD manufacturer must provide:

- Information on the structure and function of the EWD;

- Information on the suitability and functioning of the EWD under specific environmental conditions;
- A list of endoscopes that can be reprocessed in the EWD and of the required connectors.

Based on this information, the clinical service provider should check whether the endoscopes intended for reprocessing appear in the list provided by the manufacturer.

The validation should be performed as soon as the EWD is installed according to the manufacturer's instructions and to local safety regulations once all components and utilities are available. An example of a prerequisites checklist is shown in Appendix 1 ( $>$ Table $\mathbf{A} \mathbf{1})$.

\subsection{Installation qualification}

Installation qualification is the process of obtaining and documenting evidence that the EWD has been supplied and installed in accordance with its specifications. Checks must be carried out to confirm that all ordered items have been received and that the EWD has been installed according to specifications (e.g., water quality, power supply; see the example installation checklist in Appendix 1, > Table A2).

\subsection{Operational qualification}

Operational qualification is the process of obtaining and documenting evidence that the installed EWD operates within predetermined limits when used in accordance with its operating procedures (see the example operational qualification checklist in Appendix 1, > Table A3). For instance checks need to be carried out to confirm that:

- The leak test and the flow control function according to their specifications;

- Alarms function properly;

- The temperature profile is in line with specifications;

- The dosage pumps for the chemicals deliver the correct quantities.

\subsection{Performance qualification}

Performance qualification is the process of obtaining and documenting evidence that the EWD, as installed and operated in accordance with operational procedures, consistently performs in accordance with predetermined criteria and thereby yields reprocessing of instruments according to the specifications.

The performance qualification focuses on the "in-use" testing condition of the EWD. The efficacy of the cleaning and disinfection steps should be evaluated (see the example checklist for performance qualification in Appendix 1, $>$ Table A4).

The ISO/TS 15883-5(4) standard offers a variety of test soils and methods for demonstrating cleaning efficacy, but there is currently no consensus in the related ISO working group regarding preferred test soils and methods.

National guidelines and regulations on validation and hygiene in endoscopy vary from country to country. Test procedures for performance qualification must be modified according to national regulations. 


\subsection{Considerations in the case of modifications}

If the results of the validation show that modifications of the EWD and/or the reprocessing procedure are required, it is the responsibility of the clinical service provider to ensure that the modification is approved by the manufacturer of the EWD.

\section{Routine inspections}

Routine inspections must demonstrate that the reprocessing procedure runs within the prespecified parameters to consistently deliver the predefined performance.

The extent and frequency of the routine inspections must be defined on the basis of:

- EN ISO 15883-4 Annex C [3];

- National recommendations (see section 10.3 for a comparison of selected national guidelines);

- The results of the process validation of each individual EWD;

- Specific risk assessment.

Routine inspections cover daily functional tests and periodic tests (see the example checklist for routine inspections in Appendix 1, > Table A5).

Daily functional tests are specified by the manufacturer or the clinical service provider, and cover, for example, spray arm rotation, filling level of chemical containers, and cleanliness of sieves.

In contrast to the daily functional test, the documentation of each reprocessing cycle (e.g., as paper printouts or electronically stored data) shows that the particular reprocessing cycle has been completed within the required process parameters.

Periodic tests cover technical, analytical, and microbiological aspects:

- Routine checks of technical/analytical parameters (e.g. temperature, water quality) may reduce the number of required microbiological tests on endoscopes, as the technical tests demonstrate that the EWD is working within its specifications.

- For microbiological testing of endoscopes, it is recommended that the ESGE-ESGENA guideline on microbiological surveillance testing in endoscopy [14] should be followed.

If any routine test result does not meet a specification, it is the responsibility of the clinical service provider to initiate corrective actions in the entire reprocessing cycle, such as:

- Maintenance of the EWD;

- Checking water quality;

- Maintenance of the endoscopes involved;

- Review of the entire reprocessing process.

\section{Frequency of validation and routine testing}

\subsection{Validation}

A complete validation process is necessary before routine use. This first validation is a baseline assessment of the adequacy of effectiveness [2, 3].

\subsection{Requalification}

Requalification must be performed:

- On a regular basis according to EN ISO 15883 [2,3] and taking into account additional national requirements (see section 10.3, which includes a comparison of selected national guidelines);

- After each major change in the reprocessing cycle (e.g., temperature, process chemicals);

- After major repair.

This must be done in order to document that the reprocessing procedure still achieves the same required, reproducible results.

Typically requalifications cover elements of operational and performance qualification, depending on the reason for the requalification. Regular maintenance of EWDs is an element of quality management and is essential for safe use of EWDs. It ensures the early detection of possible weaknesses and defects in an EWD.

\subsection{Routine inspections}

In order to confirm the correct functioning of the EWD, routine tests are recommended on a regular basis (e.g. daily, weekly, quarterly) depending on the results of validation/requalification and taking into account relevant national requirements. The elements of routine inspections are described in section 8 .

The frequency of routine testing varies across Europe; examples are given in section 10 .

\section{ESGE-ESGENA statements based on comparison of national guidelines for validation and routine testing \\ 10.1 International standards and national guidelines}

In general, ISO/EN standards are developed for manufacturers in order to define common requirements and test methods for devices at a global, regional, or national level. Although ISO/EN standards have a uniform structure, they are often very difficult to interpret because of crosslinks to other parts of the same family of standards and also to chapters or annexes within a standard itself. Furthermore, the EN ISO 15883 family of standards with its different parts opens the opportunity for national modifications. These modifications, related to performance requirements and test methods, may be made to fulfill local requirements demanded by national authorities, or in order to meet local market needs. 
- Table2 Source guidelines [5-8].

\begin{tabular}{|c|c|c|c|c|}
\hline Country & United Kingdom & Netherlands & Austria & Germany \\
\hline Author & $\begin{array}{l}\text { Department } \\
\text { of Health }\end{array}$ & $\begin{array}{l}\text { Steering Group for Flexible } \\
\text { Endoscope Cleaning and Disin- } \\
\text { fection (SFERD) on behalf of: } \\
\text { - Federation for Medical } \\
\text { Technology } \\
\text { - Dutch Nurse Association: } \\
\text { Gastroenterology and } \\
\text { Hepatology Division } \\
\text { - Sterilization Association of } \\
\text { the Netherlands } \\
\text { - Dutch Society of Experts on } \\
\text { Sterile Medical Devices } \\
\text { - Dutch Society for Infection } \\
\text { Prevention and Control in } \\
\text { the Health Care Setting }\end{array}$ & $\begin{array}{l}\text { Österreichische Gesellschaft } \\
\text { für Sterilgutversorgung (ÖGSV, } \\
\text { Austrian Society for Supply of } \\
\text { Sterile Goods) }\end{array}$ & $\begin{array}{l}\text { Deutsche Gesellschaft für } \\
\text { Krankenhaushygiene (DGKH) } \\
\text { Deutsche Gesellschaft für } \\
\text { Endoskopie-Assistenzpersonal } \\
\text { (DEGEA) } \\
\text { Deutsche Gesellschaft für } \\
\text { Sterilgutversorgung e.V. } \\
\text { (DGSV) } \\
\text { Deutsche Gesellschaft für } \\
\text { Verdauungs- und Stoff- } \\
\text { wechselkrankheiten (DGVS) } \\
\text { Arbeitskreis Instrumenten- } \\
\text { aufbereitung (AKI) } \\
\text { Arbeitskreis der Hersteller von } \\
\text { Reinigungs-Desinfektions- } \\
\text { geräten (AK RDG) } \\
\text { Endoskophersteller }\end{array}$ \\
\hline Title & $\begin{array}{l}\text { Choice Framework } \\
\text { for local Policy and } \\
\text { Procedures CFPP } 01 \text { - } \\
06 \text { - Decontamination } \\
\text { of flexible endo- } \\
\text { scopes: Validation } \\
\text { and verification }\end{array}$ & $\begin{array}{l}\text { Professional Standard Hand- } \\
\text { book Cleaning and Disinfection } \\
\text { Flexible Endoscopes }\end{array}$ & $\begin{array}{l}\text { Leitlinie für die Prüfung, } \\
\text { Validierung und Überwachung } \\
\text { von maschinellen Reinigungs-/ } \\
\text { Desinfektionsverfahren für } \\
\text { flexible Endoskope }\end{array}$ & $\begin{array}{l}\text { Leitlinie zur Validierung } \\
\text { maschineller Reinigungs- } \\
\text { Desinfektionsprozesse zur } \\
\text { Aufbereitung thermolabiler } \\
\text { Endoskope }\end{array}$ \\
\hline $\begin{array}{l}\text { Date of } \\
\text { publication }\end{array}$ & 2013 & $\begin{array}{l}2009 \text { - Dutch original version } \\
\text { (Version 1.0) } \\
2016 \text { - Update } \\
2017 \text { - English translation }\end{array}$ & $\begin{array}{l}2013 \text { - guideline } \\
\text { Annex } 1 \text { (published in 2015) }\end{array}$ & 2011 \\
\hline Where to find? & $\begin{array}{l}\text { https://www.gov.uk/ } \\
\text { government/publica- } \\
\text { tions/management- } \\
\text { and-decontamina- } \\
\text { tion-of-flexible-endo- } \\
\text { scopes }\end{array}$ & $\begin{array}{l}\text { http://www.infectiepreventieo- } \\
\text { pleidingen.nl/downloads/ } \\
\text { SFERDHandbook4_1.pdf }\end{array}$ & $\begin{array}{l}\text { http://www.oegsv.com/guide- } \\
\text { lines/guidelines2014.htm }\end{array}$ & $\begin{array}{l}\text { http://www.krankenhaushy- } \\
\text { giene.de/pdfdata/leitlinien/Va- } \\
\text { maReDeZuAuThEn_weiss.pdf }\end{array}$ \\
\hline
\end{tabular}

National guidelines are perfect opportunities to describe the different steps of validation and routine testing according to EN ISO 15883 from the users' point of view, bearing in mind national requirements and test methods.

\subsection{Development of national guidelines}

National guidelines dealing with process validation and routine testing of reprocessing of thermolabile endoscopes in EWDs have been established in various European countries. This section focuses on comparison of four national guidelines (from Austria, Germany, Netherlands, and the UK) [5-8].

These national guidelines were published between 2009 and 2015 by national health authorities, by hygiene societies or by groups of experts in the field of endoscope reprocessing ( Table 2).

\subsection{Comparison of national guidelines and the resulting statements}

The four abovementioned national guidelines were compared by evaluating their content for each step of the validation procedure and routine testing. The statements highlight the main points and similarities in the guidelines.

\subsection{Prerequisites}

Quality management at the endoscopy unit is the key element of the prerequisites for validation. All four guidelines describe, in a more or less detailed fashion, elements of quality management as prerequisites, such as workflow, responsibility, and risk assessment ( $\triangleright$ Table 3 ). Some guidelines also mention the necessity for checking with the EWD manufacturer that all endoscopes intended to be reprocessed using the EWD are compatible with that machine. 
$\checkmark$ Table 3 Prerequisites.

\begin{tabular}{|c|c|c|c|c|}
\hline & United Kingdom & Netherlands & Austria & Germany \\
\hline $\begin{array}{l}\text { Organization/ } \\
\text { Process }\end{array}$ & $\begin{array}{l}\text { 1. Operational responsibili- } \\
\text { ties together with advice } \\
\text { on the procurement and } \\
\text { operation of washer- } \\
\text { disinfector } \\
\text { 2. Definition of responsibili- } \\
\text { ties in the endoscope } \\
\text { reprocessing area } \\
\text { 3. Define persons with key } \\
\text { functionalities }\end{array}$ & $\begin{array}{l}\text { 1. A flexible endoscope disin- } \\
\text { fection expert shall be ap- } \\
\text { pointed and he/she shall } \\
\text { have appropriate authority } \\
\text { (independent position) } \\
\text { 2. Detailed description of re- } \\
\text { sponsibilities of other staff } \\
\text { involved in endoscopy } \\
\text { 3. Set-up detailed workflows } \\
\text { for reprocessing of each } \\
\text { instrument } \\
\text { 4. Confirmation by washer- } \\
\text { disinfector manufacturer, } \\
\text { that all endoscopes in- } \\
\text { tended to be used are } \\
\text { reprocessable }\end{array}$ & $\begin{array}{l}\text { 1. Establish quality manage- } \\
\text { ment system according to } \\
\text { Österreichische Gesell- } \\
\text { schaft für Sterilgutversor- } \\
\text { gung (ÖGSV) guidelines } \\
\text { 2. Risk assessment and clas- } \\
\text { sification (Spaulding) on } \\
\text { all products to be repro- } \\
\text { cessed } \\
\text { 3. Documentation about } \\
\text { organization and respon- } \\
\text { sibilities }\end{array}$ & $\begin{array}{l}\text { 1. Establishment of quality } \\
\text { management system } \\
\text { 2. Risk assessment and classi- } \\
\text { fication (Spaulding) on all } \\
\text { products to be reprocessed } \\
\text { 3. Categorization into endo- } \\
\text { scope families of all endo- } \\
\text { scopes intended to be } \\
\text { used, }\end{array}$ \\
\hline Staff & $\begin{array}{l}\text { 1. Training of staff involved in } \\
\text { endoscope reprocessing is } \\
\text { essential prerequisite }\end{array}$ & $\begin{array}{l}\text { 1. All staff require extensive } \\
\text { training }\end{array}$ & $\begin{array}{l}\text { 1. Qualified staff in leading } \\
\text { function as well as perform- } \\
\text { ing functions }\end{array}$ & 1. Qualified staff required \\
\hline Environment & $\begin{array}{l}\text { 1. Dedicated reprocessing } \\
\text { room; recommendation: } \\
\text { clean-side/dirty-side con- } \\
\text { cept } \\
\text { 2. Reprocessing shall not take } \\
\text { place at the endoscopy } \\
\text { room } \\
\text { 3. Transportation of used } \\
\text { endoscopes between hos- } \\
\text { pitals shall be prevented }\end{array}$ & $\begin{array}{l}\text { 1. Dedicated reprocessing } \\
\text { room; recommendation: } \\
\text { clean-side/dirty-side con- } \\
\text { cept } \\
\text { 2. In the case that reproces- } \\
\text { sing needs to be performed } \\
\text { in a single room, a clear } \\
\text { logical process shall be } \\
\text { established }\end{array}$ & $\begin{array}{l}\text { No recommendations in the } \\
\text { ÖGSV validation guideline. } \\
\text { However recommendation } \\
\text { for clean-side/dirty-side } \\
\text { concept in another ÖGSV } \\
\text { guideline dealing with re- } \\
\text { sponsibilities on reproces- } \\
\text { sing of medical devices. }\end{array}$ & $\begin{array}{l}\text { Dedicated reprocessing } \\
\text { room; recommendation: } \\
\text { clean-side/dirty-side con- } \\
\text { cept }\end{array}$ \\
\hline
\end{tabular}

\section{STATEMENT}

The clinical service provider should obtain confirmation from the EWD manufacturer that all endoscopes intended to be used can be reprocessed in the EWD.

\subsubsection{Installation qualification}

Installation qualification activities are specified quite differently in the four referenced guidelines ( $\triangleright$ Table 4 ).

The guidelines have different views about the responsibility for and performance of the installation qualification. The German guideline specifies that the clinical service provider is responsible for all of the validation, including the installation qualification. In the UK and Austrian guidelines the responsibility for the necessary activities is assigned to the manufacturer/ contractor supplying the EWD, whereas the Dutch guideline assigns the responsibility to an internal or external endoscope reprocessing expert.

All guidelines recommend that internal or external qualified personnel must perform the installation qualification. The UK, Austrian, and German guidelines focus on correct installation of the EWD and supply of water, electrical power, etc, while only the Dutch guidelines require a list of compatible endoscopes.

\section{STATEMENT}

The installation qualification can be performed by different parties but national guidelines should define who has the responsibilities, taking into account legal requirements.

\subsubsection{Operational qualification}

Operational qualification activities are performed at the point of use by internal or external qualified personnel ( $>$ Tables 5 ).

The UK, Austrian, and German guidelines recommend performance of parametric tests. Results must be in line with the EWD specifications, defined by the EWD manufacturer during type and works tests. The extent of the tests is similar. Only the Dutch guideline does not define parametric tests in detail, but it can be assumed that their extent is similar to those listed in the other guidelines.

\section{STATEMENT}

The operational qualification should include parametric tests to verify that the EWD is working according to its specifications. 
> Table4 Installation qualification.

\begin{tabular}{|c|c|c|c|c|}
\hline & United Kingdom & Netherlands & Austria & Germany \\
\hline Responsibility & $\begin{array}{l}\text { Contractor/washer- } \\
\text { disinfector manufacturer }\end{array}$ & $\begin{array}{l}\text { Endoscope reprocessing } \\
\text { expert or contractor }\end{array}$ & $\begin{array}{l}\text { Washer-disinfector } \\
\text { manufacturer }\end{array}$ & Clinical service provider \\
\hline $\begin{array}{l}\text { Performed } \\
\text { by: }\end{array}$ & Authorized engineer & $\begin{array}{l}\text { Any competent party } \\
\text { (supplier of the washer-dis- } \\
\text { infector, the medical tech- } \\
\text { nology/clinical physics de- } \\
\text { partment of the hospital, } \\
\text { validation company) }\end{array}$ & $\begin{array}{l}\text { Manufacturer in cooperation } \\
\text { with competent person from } \\
\text { hospital }\end{array}$ & $\begin{array}{l}\text { Internal and/or external (con- } \\
\text { tractor) qualified persons } \\
\text { Qualification requirements } \\
\text { according guideline }\end{array}$ \\
\hline $\begin{array}{l}\text { Tests/ } \\
\text { Inspections }\end{array}$ & $\begin{array}{l}\text { 1. Water hardness } \\
\text { 2. Final rinse water conduc- } \\
\text { tivity (if pure water used) } \\
\text { 3. Residual chemical additives } \\
\text { 4. Water supply temperature } \\
\text { 5. Water supply pressure }\end{array}$ & $\begin{array}{l}\text { 1. Elements of verification of } \\
\text { the system specification of } \\
\text { the endoscope washer- } \\
\text { disinfector } \\
\text { 2. List of compatible endo- } \\
\text { scopes }\end{array}$ & $\begin{array}{l}\text { 1. Complete delivery of prod- } \\
\text { uct and accessories (ac- } \\
\text { cording to order) } \\
\text { 2. Correct installation of the } \\
\text { washer-disinfector } \\
\text { 3. All supplies available (re- } \\
\text { processing chemicals, wa- } \\
\text { ter, electrical power, etc) }\end{array}$ & $\begin{array}{l}\text { 1. Correct installation } \\
\text { 2. All supplies available (repro- } \\
\text { cessing chemicals, water, } \\
\text { electrical power, etc) } \\
\text { 3. Software interfaces } \\
\text { 4. Compliance with standards } \\
\text { 5. Compilation of documents }\end{array}$ \\
\hline
\end{tabular}

\begin{tabular}{|c|c|c|c|c|}
\hline & United Kingdom & Netherlands & Austria & Germany \\
\hline Performed by: & $\begin{array}{l}\text { Competent person (decon- } \\
\text { tamination) or contractor }\end{array}$ & $\begin{array}{l}\text { Expert in cleaning and disin- } \\
\text { fection of scopes }\end{array}$ & $\begin{array}{l}\text { Manufacturer in cooperation } \\
\text { with the local person respon- } \\
\text { sible for hygiene/expert and } \\
\text { independent consultant }\end{array}$ & $\begin{array}{l}\text { Internal and/or external (con- } \\
\text { tractor) qualified persons } \\
\text { Qualification requirements } \\
\text { according guideline }\end{array}$ \\
\hline $\begin{array}{l}\text { Tests/ } \\
\text { Inspections }\end{array}$ & $\begin{array}{l}\text { 1. Verification of calibration } \\
\text { 2. Chemical dosage testing } \\
\text { 3. Thermometric tests } \\
\text { 4. Leak and patency testing } \\
\text { 5. Contact times } \\
\text { 6. Check water quality } \\
\text { 7. Error messages }\end{array}$ & $\begin{array}{l}\text { 1. Elements of verification of } \\
\text { the system specification of } \\
\text { the endoscope washer-dis- } \\
\text { infectors }\end{array}$ & $\begin{array}{l}\text { Technical verification } \\
\text { aspects only: } \\
\text { 1. Verification of calibration } \\
\text { 2. Chemical dosage testing } \\
\text { 3. Thermometric tests } \\
\text { 4. Leak and patency testing } \\
\text { 5. Contact times } \\
\text { 6. Check water quality }\end{array}$ & $\begin{array}{l}\text { 1. Verification of calibration } \\
\text { 2. Chemical dosage testing } \\
\text { 3. Thermometric tests } \\
\text { 4. Leak and patency testing } \\
\text { 5. Contact times } \\
\text { 6. Check water quality } \\
\text { 7. Error messages }\end{array}$ \\
\hline
\end{tabular}

\subsubsection{Performance qualification}

The extent of performance qualification testing is quite different in the four national guidelines ( $>$ Table 6 ). For some parameters, the results of type tests made by the manufacturer are accepted for the performance qualification in respect to chemical residues on endoscope surfaces (Netherlands, Austria) or thermometric control during the process (Netherlands). Other national guidelines (UK, Germany) demand specific tests for these parameters. Cleaning performance tests are required in all guidelines, but at different levels, applying surrogate devices that have lumens and/or endoscopes. Tests of the microbiological status of used endoscopes and of the final rinse water are systematically or occasionally required in all four guidelines. Additional microbiological tests are performed with surrogate devices in Austria and Germany.

\section{STATEMENT}

Testing of cleaning performance, microbiological testing of routinely used endoscopes, and the quality of the final rinse water should be considered in all local guidelines. The extent of these tests depends on local requirements. According to the results of type testing, other parameters can be tested if local regulatory authorities accept this. Chemical residues on endoscope surfaces should be searched for, if acceptable test methods are available.

\subsubsection{Routine inspections}

Testing beyond the validation procedure can be divided into daily user maintenance, periodic microbiological tests, and periodic technical/functional tests ( $>$ Table 7 ).

In the frame of daily user maintenance activities, all guidelines recommend checking process parameters and visual cleanliness of EWDs and/or endoscopes. However, recommendations are different for other measures such as checking of filters and adapters or of availability of chemicals 
- Table6 Performance qualification.

\begin{tabular}{|c|c|c|c|c|}
\hline & United Kingdom & Netherlands & Austria & Germany \\
\hline Performed by: & $\begin{array}{l}\text { Competent person (deconta- } \\
\text { mination) or contractor }\end{array}$ & $\begin{array}{l}\text { Expert in cleaning and } \\
\text { disinfection of scopes }\end{array}$ & $\begin{array}{l}\text { Manufacturer in cooperation } \\
\text { with the local person respon- } \\
\text { sible for hygiene/expert and } \\
\text { independent consultant }\end{array}$ & $\begin{array}{l}\text { Internal and/or external } \\
\text { (contractor) qualified } \\
\text { persons } \\
\text { Qualification requirements } \\
\text { according guideline }\end{array}$ \\
\hline Test load & $\begin{array}{l}\text { Surrogate device and if } \\
\text { necessary additional test } \\
\text { devices }\end{array}$ & $\begin{array}{l}\text { Surrogate devices and used } \\
\text { endoscopes }\end{array}$ & $\begin{array}{l}\text { Surrogate devices and endo- } \\
\text { scopes }\end{array}$ & $\begin{array}{l}\text { Surrogate devices and one } \\
\text { endoscope from each endo- } \\
\text { scope product family, but at } \\
\text { least three. }\end{array}$ \\
\hline Cleaning & $\begin{array}{l}\text { Inspection after cleaning } \\
\text { steps: } \\
\text { 1. Surrogate device } \\
\text { 2. Chamber walls and load } \\
\text { carrier with test soil }\end{array}$ & $\begin{array}{l}\text { Inspection after cleaning } \\
\text { steps: } \\
\text { 1. Surrogate device } \\
\text { 2. Chamber walls and load } \\
\text { carrier with test soil } \\
\text { At end of complete cycle } \\
\text { before drying: } \\
\text { 1. Visual inspection of outer } \\
\text { surfaces of endoscopes }\end{array}$ & $\begin{array}{l}\text { Inspection after cleaning } \\
\text { steps: } \\
\text { 1. Surrogate device } \\
\text { 2. Chamber walls and load } \\
\text { carrier with test soil } \\
\text { At end of complete cycle } \\
\text { before drying: } \\
\text { 1. Swabbing of used endo- } \\
\text { scopes }\end{array}$ & $\begin{array}{l}\text { Inspection after cleaning } \\
\text { steps: } \\
\text { 1. Surrogate device } \\
\text { 2. Chamber walls and load } \\
\text { carrier with test soil }\end{array}$ \\
\hline $\begin{array}{l}\text { Lumen } \\
\text { decontamina- } \\
\text { tion test }\end{array}$ & $\begin{array}{l}\text { Optional: } \\
\text { Microbiological status } \\
\text { tested on routine endoscope } \\
\text { at end of complete cycle }\end{array}$ & $\begin{array}{l}\text { Occasional: } \\
\text { Microbiological status tests } \\
\text { only required in case of } \\
\text { specific defects or outbreaks }\end{array}$ & $\begin{array}{l}\text { Mandatory: } \\
\text { Microbiological status } \\
\text { tested on surrogate devices } \\
\text { and routine endoscope at } \\
\text { end of complete cycle }\end{array}$ & $\begin{array}{l}\text { Mandatory: } \\
\text { Microbiological status } \\
\text { tested on surrogate devices } \\
\text { and routine endoscope at } \\
\text { end of complete cycle }\end{array}$ \\
\hline $\begin{array}{l}\text { Chemical } \\
\text { residues }\end{array}$ & Tests are required & No tests are required & No tests are required & Tests are required \\
\hline $\begin{array}{l}\text { Microbiological } \\
\text { quality of } \\
\text { water supply }\end{array}$ & Tests are required & Tests are required & $\begin{array}{l}\text { Tests are required for } \\
\text { incoming water and the } \\
\text { sump water at the end of } \\
\text { the final rinsing cycle }\end{array}$ & $\begin{array}{l}\text { Tests are required for } \\
\text { incoming water }\end{array}$ \\
\hline
\end{tabular}

The necessity for microbiological tests is judged differently amongst guidelines. Recommendations for endoscope lumen decontamination tests and water supply tests vary from no recommendation being given to weekly testing.

Periodic technical/functional tests are carried out at least yearly during requalification. However, some guidelines recommend shorter intervals for some tests, such as cleaning efficacy tests or channel non-obstruction tests.

In general, the national guidelines focus differently with regard to the following aspects:

- The Austrian guidelines highlight verification of the cleaning performance, by recommending the use of indicators for cleaning efficacy every 2 weeks;

- The British and the Dutch guidelines focus more on the technical compliance of the EWD and also on safety issues;

- The German guideline recommends risk analyses in some cases, to find individual and appropriate test frequencies.

\section{STATEMENT}

National guidelines should consider both technical and performance criteria. Individual risk analyses performed in the validation phase and requalification are helpful for defining appropriate test frequencies for routine inspections.

\section{Summary}

It is the responsibility of the clinical service provider to ensure safe and efficient reprocessing of thermolabile endoscopes according to national guidelines and manufacturers' recommendations. The validation and routine testing of automated procedures, according to EN ISO 15883, parts 1, 4, and ISO/TS 15883-5, are key elements in this process. Four national guidelines focusing on process validation and routine testing for reprocessing endoscopes in EWDs were compared. Though these four national guidelines did reveal a certain variety, it was possible to develop common statements. 
Table 7 Routine inspections.

\begin{tabular}{|c|c|c|c|c|}
\hline & United Kingdom & Netherlands & Austria & Germany \\
\hline \multicolumn{5}{|l|}{ Daily user maintenance } \\
\hline $\begin{array}{l}\text { Check of process } \\
\text { parameters }\end{array}$ & $\begin{array}{l}\text { Daily (automatic } \\
\text { control test) }\end{array}$ & Daily & Every batch & Daily \\
\hline $\begin{array}{l}\text { Visual cleanliness of endoscope } \\
\text { washer-disinfector (EWD) and/or } \\
\text { endoscopes }\end{array}$ & Daily & Daily & Every batch & Daily \\
\hline Check filter in EWD & Daily & Daily & No recommendation & Daily \\
\hline $\begin{array}{l}\text { Connection of adapter and/or } \\
\text { channel separators }\end{array}$ & No recommendation & Daily & No recommendation & Daily \\
\hline $\begin{array}{l}\text { Cleaning and disinfection agent } \\
\text { available }\end{array}$ & No recommendation & Daily & No recommendation & Daily \\
\hline Water quality (conductivity) & No recommendation & No recommendation & Yes (weekly) & Daily \\
\hline \multicolumn{5}{|l|}{ Periodic microbiological tests } \\
\hline $\begin{array}{l}\text { Endoscope lumen decontami- } \\
\text { nation test }\end{array}$ & $\begin{array}{l}\text { Only in cases of out- } \\
\text { breaks and suspected } \\
\text { transmission }\end{array}$ & $\begin{array}{l}\text { Only in cases of out- } \\
\text { breaks and suspected } \\
\text { transmission }\end{array}$ & Yearly (revalidation) & Quarterly \\
\hline Water supply & Weekly & No recommendation & $\begin{array}{l}\text { Yearly (revalidation) } \\
\text { (Tests on the sump } \\
\text { water at the end of the } \\
\text { final rinsing cycle) }\end{array}$ & Yearly (revalidation) \\
\hline \multicolumn{5}{|l|}{$\begin{array}{l}\text { Periodic technical/functional } \\
\text { tests }\end{array}$} \\
\hline Temperature & Quarterly & Yearly (revalidation) & Yearly (revalidation) & $\begin{array}{l}\text { Daily-yearly } \\
\text { (depending on the } \\
\text { monitoring unit of the } \\
\text { washer-disinfector) }\end{array}$ \\
\hline Dosing and/or water level & Yearly (revalidation) & Yearly (revalidation) & Yearly (revalidation) & Yearly (revalidation) \\
\hline $\begin{array}{l}\text { Final rinse water (e. g. } \\
\text { conductivity, water hardness) }\end{array}$ & Quarterly & Yearly (revalidation) & Weekly & Yearly (revalidation) \\
\hline $\begin{array}{l}\text { Channel obstruction and non- } \\
\text { connection }\end{array}$ & Quarterly & Quarterly & No recommendation & No recommendation \\
\hline $\begin{array}{l}\text { Cleaning efficacy (e.g. test } \\
\text { dummy, surrogate endoscope) }\end{array}$ & No recommendation & Quarterly & Every 2 weeks & $\begin{array}{l}\text { According to risk } \\
\text { assesment }\end{array}$ \\
\hline $\begin{array}{l}\text { Cleaning efficacy (e.g. residual } \\
\text { test, swab test) }\end{array}$ & Quarterly & No recommendation & Yearly (revalidation) & No recommendation \\
\hline Disinfection & $\begin{array}{l}\text { Yearly (revalidation): } \\
\text { Temperature and } \\
\text { chemical dosing check }\end{array}$ & $\begin{array}{l}\text { Yearly (revalidation): } \\
\text { Temperature and } \\
\text { chemical dosing check }\end{array}$ & $\begin{array}{l}\text { Yearly (revalidation): } \\
\text { Temperature and } \\
\text { chemical dosing check } \\
\text { Swabs and lumen } \\
\text { decontamination test }\end{array}$ & $\begin{array}{l}\text { Yearly (revalidation): } \\
\text { Temperature and } \\
\text { chemical dosing check } \\
\text { Lumen } \\
\text { decontamination test }\end{array}$ \\
\hline
\end{tabular}


U. Beilenhoff has provided consultancy to Boston Scientific since July 2017. H. Biering has done customer presentations and trainings, moderated workshops, and provided consultancy to Richard Wolf $\mathrm{GmbH}$, Olympus Europa, Dr. Weigert, and Ecolab. R. Blum is employed by Olympus Europa, who hold patents on endoscopes in general; he is a member of the DIN/CEN/ISO TC/198/WG13 standards group for safe reprocessing of endoscopes. M. Cimbro has been employed by CBC Europe since 2002; she has been a consultant since 2011 to ANOTE-ANIGEA (Italian Association of Gastroenterology and Endoscopy Nurses). M. Jung's hospital has received sponsorship from Olympus Optical and other companies for an EUS/endoscopy course (22nd September 2017). M. Pietsch's department has received thirdparty funding from Olympus for a research project, from 2015 to 2017. L. Pineau has provided training on hygiene and medical device evaluation for Pentax, Olympus, and Fujifilm, from 1999 to 2017. T. Ponchon has served on an advisory board for Fujifilm (January 2015 to October 2017). J. Brljak, J.-M. Dumonceau, C. Hassan, C. Neumann, S. Rejchrt, J.-F. Rey, V. Schmidt, J. Tillett, and J. van Hooft have no competing interests.

\section{References}

[1] Beilenhoff U, Neumann CS, Biering H. ESGE Guidelines Committee. et al. ESGE/ESGENA guideline for process validation and routine testing for reprocessing endoscopes in washer-disinfectors, according to the European Standard prEN ISO 15883 parts 1, 4 and 5. Endoscopy 2007; 39: $85-94$

[2] International Organization for Standardization. ISO 15883-1:2006. Washer-disinfectors - Part 1: General requirements, terms and definitions and tests. Available from: 2017: https://www.iso.org/standard/41076.html Accessed: September 62017

[3] International Organization for Standardization. ISO 15883-4:2008. Washer-disinfectors - Part 4: Requirements and tests for washer-disinfectors employing chemical disinfection for thermolabile endoscopes. Available from: 2017: https://www.iso.org/standard/42060. html Accessed: September 62017

[4] International Organization for Standardization. ISO/TS 158835:2005. Washer-disinfectors - Part 5: Test soils and methods for demonstrating cleaning efficacy. Available from: 2017: https://www. iso.org/standard/41175.htm Accessed: September 62017
[5] DGKH, AKI, DGEA, DGSV. Leitlinie zur Validierung maschineller Reinigungs- Desinfektionsprozesse zur Aufbereitung thermolabiler Endoskope, Zentralsterilisation Suppl. 3/2011. Available from: 2017: http://www.krankenhaushygiene.de/pdfdata/leitlinien/VamaReDeZuAuThEn_weiss.pdf Accessed: October 182017

[6] Department of Health (England and Wales). Health Technical Memorandum [HTM] 01-06). Part D: Decontamination of flexible endoscopes: validation and verification (including storage/drying cabinets). 2016. Available from: 2017: https://www.gov.uk/government/ publications/management-and-decontamination-of-flexible-endoscopes Accessed: September 62017

[7] Österreichische Gesellschaft für Sterilgutversorgung (ÖEGSV) (Austrian Society for Supply of Sterile Goods). Leitlinie für die Prüfung, Validierung und Überwachung von maschinellen Reinigungs-/ Desinfektionsverfahren für flexible Endoskope 2013. Available from: 2017: http://www.oegsv.com/guidelines/guidelines2014.htm Accessed: October 182017

[8] Steering Group for Flexible Endoscope Cleaning and Disinfection (SFERD). Professional standard handbook cleaning and disinfection flexible endoscopes. Version 4.1, September 2017. Available from: 2017: http://www.infectiepreventieopleidingen.nl/downloads/ SFERDHandbook4_1.pdf Accessed: October 182017

[9] Deutsche Gesellschaft für Sterilgutversorgung (DGSV). Qualification requirements for persons entrusted with validation. Zentralsterilisation 2005; 13: 375-376

[10] ESGE-ESGENA Guideline. Cleaning and disinfection in gastrointestinal endoscopy. Endoscopy 2008; 40: 939-957

[11] Kommission für Krankenhaushygiene und Infektionsprävention. Anforderungen der Hygiene an die baulich-funktionelle Gestaltung und apparative Ausstattung von Endoskopieeinheiten. Bundesgesundheitsblatt 2002; 45: 412-414

[12] International Organization for Standardization. ISO 17664:2004. Sterilization of medical devices - Information to be provided by the manufacturer for the processing of resterilizable medical devices. Available from: 2017: https://www.iso.org/standard/31456.html Accessed: September 62017

[13] ESGE Newsletter. Definition of "endoscope families" as used in EN ISO 15883. Endoscopy 2013; 45: 156- 157

[14] ESGE-ESGENA guideline for quality assurance in reprocessing. Microbiological surveillance testing in endoscopy. Endoscopy 2007; 39: $175-181$ 


\section{Appendix 1: Example checklists for validation and routine testing of an endoscope washer-disinfector}

- TableA1 Example of prerequisites checklist.

\begin{tabular}{|l|l|l|}
\hline & Available/Done & Comments \\
\hline $\begin{array}{l}\text { Purpose-designed reprocessing room, separate from procedure rooms and ideally separated into } \\
\text { contaminated and clean working areas }\end{array}$ & \\
\hline $\begin{array}{l}\text { Availability of all water, electricity, drainage, air supplies according to manufacturer's installation } \\
\text { requirements }\end{array}$ & \\
\hline Space or room for storage of process chemicals & & \\
\hline List of endoscopes intended to be reprocessed & & \\
\hline Workflow (including pre-cleaning activities) for all endoscopes intended to be reprocessed & \\
\hline Definition of responsibilities & & \\
\hline All persons in charge of reprocessing having adequate education and reprocessing knowledge & \\
\hline Hygiene plan/Documentation of all hygiene measures & \\
\hline Information about health and safety requirements & \\
\hline
\end{tabular}

- Table A2 Example of installation qualification checklist.

\begin{tabular}{|l|l|l|}
\hline & Available/Done & Comments \\
\hline $\begin{array}{l}\text { Endoscope washer-disinfector (EWD) documentation (including type of device, manufacturer, serial } \\
\text { number, year of production) }\end{array}$ & \\
\hline $\begin{array}{l}\text { Documentation on the process chemicals applied in the EWD and for pre-cleaning (names of } \\
\text { products, manufacturer, type of product; use instructions) }\end{array}$ & \\
\hline Instructions for reprocessing of all endoscopes intended to be used & \\
\hline All necessary information about endoscopes has been entered into EWD database & \\
\hline $\begin{array}{l}\text { Check availability of all media and other installation requirements according to EWD needs (e. g., } \\
\text { water supply, electricity) - for a complete list see EN ISO 15883-1/ } 6.1 .3 .2\end{array}$ & \\
\hline
\end{tabular}

- TableA3 Example of operational qualification checklist*.

\begin{tabular}{|l|l|l|}
\hline & Available/Done & \multicolumn{1}{c|}{ Comments } \\
\hline $\begin{array}{l}\text { Check for correct set-up of endoscope washer-disinfector (EWD) (i. e., correct filters, adapters, } \\
\text { sieves, etc.) }\end{array}$ & \\
\hline Check basic functions (i. e., correct installation of all supplies (water, electrical, air) and drainage & \\
\hline $\begin{array}{l}\text { Operation tests (e. g., leak test, water inlet quantities, dosages of process chemicals, specified } \\
\text { temperatures and contact times achieved) }\end{array}$ & \\
\hline $\begin{array}{l}\text { Check of alarm functions (e. g., leak test failure alarm, insufficient dosage of chemical, temperature } \\
\text { not reached) }\end{array}$ & \\
\hline Check of correct reporting and printouts (including interface to external documentation software) \\
\hline * For a complete list see EN ISO 15883-1/-4
\end{tabular}


- TableA4 Example of performance qualification checklist.

\begin{tabular}{|l|l|l|}
\hline & Available/Done & Comments \\
\hline $\begin{array}{l}\text { Specification of process-challenging devices (PCDs) and endoscopes intended to be used for } \\
\text { performance tests }\end{array}$ & \\
\hline Check of cleaning efficacy with PCDs (see EN ISO 15883-4/6.11) & \\
\hline Check of cleaning efficacy with specified endoscopes (see EN ISO 15883-4/6.11) \\
\hline Check of final rinse water microbiological quality \\
\hline Check of disinfection efficacy with PCDs (if required by national regulations) \\
\hline Check of microbial status of specified endoscopes after reprocessing
\end{tabular}

- Table A5 Example of routine testing checklist.

\begin{tabular}{|l|l|l|}
\hline & Available/Done \\
\hline Examples of daily function tests & Comments \\
\hline User maintenance, for example: \\
\hline - Cleanliness of endoscope washer-disinfector (EWD) \\
\hline - Visual inspections (e. g., door seal, nozzles, sieves, flushing arm) \\
\hline - Process parameter check \\
\hline - Filter check \\
\hline - Availability of process chemicals \\
\hline Repetition of elements of operating tests, for example: \\
\hline - Leak test & \\
\hline - Test for correct connection of channels & \\
\hline Repetition of elements of alarm function tests, for example: \\
\hline - Leak test failure alarm \\
\hline - Flow control in channels \\
\hline Examples of periodic tests \\
\hline - Cleaning efficacy tests with process-challenging device (PCD) (according to national \\
\hline
\end{tabular}

